\title{
CONFERENCE REVIEW I Popular Music and Power. Sonic Materiality between Cultural Studies and Music Analysis, June 2016, Berlin
}

Bianca Ludewig and José Gálvez

FGPM (Research Group for Popular Music at Humboldt University of Berlin)

Bianca.Ludewig@culture.hu-berlin.de don.jose.galvez@gmail.com

The first generation of scholars specialized in popular music studies worked in challenging times back in the 1970s because musicology did not accept popular music as an autonomous field of music research with its own theoretical foundation, methodological challenges, and research questions. From this first generation - including Franco Fabbri, Richard Middleton, John Shepherd, and Philip Tagg - one researcher came from a socialist country: Peter Wicke. Wicke studied musicology in East Berlin and gained his doctoral degree on popular music and aesthetics in 1980. After becoming adjunct research professor at the Department of Music at Carleton University Ottawa, he established at the Humboldt University of Berlin the Chair of Theory and History of Popular Music the first professorial role in Germany exclusively dedicated to popular music studies. In his career, Wicke has consistently stressed the sociocultural dimensions and politics of popular music. Linking musicology with cultural studies, sociological theory, and media studies, Wicke delivered the theoretical foundations for a research of popular music that exceeds by far the constraints of area studies or fan perspectives.

Wicke researched the discursive formations and the industrialization of popular music, as well as its materiality and mediality as sound. The latter both focuses on the body as a cultural resource of identity formation through sound, and the impact of technologies involved in the production and experience of popular music, both 
of which have been key points of Wicke's research profile. On a methodological level, one can state that Wicke's main contribution to popular music studies is the search for analytical instruments to grasp the interrelation of culture and music as a dynamic and powerful cultural text. Concepts as music as a medium (Wicke 1990, 1992), technology of articulation (Shepherd and Wicke 1997), and the sonic (Wicke 2009, 2016) aim to connect cultural analysis and sound analysis. The impact of his work in Germanophone popular music studies is still immense today (for a current example of this, see Wicke 2017). To honor Wicke's retirement after forty-two years of teaching and researching popular music at Humboldt University Berlin, Jens Gerrit Papenburg, Wickes's research associate at the Institute of Musicology and Media Studies at Humboldt, organized a conference. The title and conception of the conference, Popular Music and Power. Sonic Materiality between Cultural Studies and Music Analysis, were intimately related to Wicke's research and career. Here follows a review of this event.

The first day began with the panel "Relational Sonic Materialities" featuring Antoine Hennion, Jochen Bonz, and Will Straw. Hennion addressed the ontological status of music as product of mediation practices, which are vital for the development of musical taste and musical pleasure. Bonz, Professor of Cultural Studies, presented a paper on music experience based on ethnographic research on electronic dance music, arguing that the dancer engages in a new space of oblivion, a jouissance of amnesia which potentially liberates from the demands and constraints of the symbolic order. Subsequently Straw discussed the decay of visual and sonic aesthetics.

In the late afternoon, a panel was committed to "Amplification, Silence, and Powerful Sounds". Kyle Devine from Oslo discussed "Loudness and Power in 'Speaker Culture'" - here speaker and listener are tuned to one another. The topic was complemented by a presentation of Jens Gerrit Papenburg about "Tactile Sound, Volume, and 'Para-Auditive' Subjects" in 1920s and 1930s Germany. He touched upon the relevance of early sound systems and volume in music and discusses the sonification of ideology and propaganda in Nazi-Germany. The day was closed by Johannes Ismaiel-Wendt's sound-lecture "Tracks'n'treks: De-Linking AfricC", which was a reenactment of the presentation of his doctoral thesis published in 2011. Ismaiel-Wendt, a musicologist and sociologist specialising in postcolonial theory, delivered a very vivid performance on the political dimensions inscribed in technical devices for music making, arguing that sounds are charged with agency and knowledge: presets and sound patterns in drum machines and other electronic music tools - like AfricC - merge African clichés with club sounds. From this perspective, drum machines follow the logic of capitalism and imperialism; race politics turn into bass politics. But racialized and colonialized sounds can also be subverted when machines are turned into "cyber-rhythmic denaturalizers".

In a similar vein, the second day of the conference began with a panel on "Sound Politics between Sensory Studies and Affect Theory". The first paper by Marie Thompson, a lecturer in Lincoln School of Film and Media, focused on the affective, material and gendered dimensions of sound, noise, and music. In her paper titled 
"Power over/Power to: Music, Affect, and Contestations of Social Space" she discussed active sonic resistance and new spaces opened by audio affective forces. Subsequently, Holger Schulze presented "A Sensological Critique on The Nanopolitics of Electric Hum in Popular Music" where he illustrated how so-called nanopolitics address our sonic bodies and listening habits. The following panel dealt with "Sound Histories" and began with a presentation of Leeds University's Derek B. Scott. He elaborated on the Silver-Age Operetta, focusing on "The Power of an Early 20th-Century Transcultural Entertainment Industry". Another historical case study was presented by musicologist Michael Rauhut on images of the US in popular music and its discourses. Rauhut illustrated the power of symbols by highlighting "Images of the US in East German Popular Music Discourse". The afternoon panel featured Marta Garcia Quiñones, a researcher with focus on listening practices. In her paper, "The Problem with Psychological Research into Popular Songs", she offered a historical review and critique of psychological and cognitivist approaches to music listening that display bias and reductions concerning states of awareness and listening practices. The final paper in this panel, by Franco Fabbri, explored the history of binaural and stereophonic listening and stressed technological and aesthetical aspects regarding popular music production.

The last panel of the conference addressed the issue of text/context where L.J. Müller, specialized in sonic articulated gender constructions within popular music, presented an analysis of "Auditive Pleasures and Gendered Body Concepts". Based on two song examples by John Lennon's "Mother" and Katy Perry's "Dark Force", Müller argued that auditive pleasure and musical embodiment are key aspects of gendered music experience. Popular music positions women as the Other by means of the male gaze and male play, which leads to the reproduction of male and white privilege. According to Müller, Perry evokes the pleasure of secret seduction and thus of desire. Her female voice produces not a pleasure of identification with the singer, but a pleasure in relation to her own body which becomes therefore a tool for seduction that does not produce a sense of self, whereas Lennon evokes a pleasure of identification with his feelings. For Müller, the neutral or natural listener does not exist because all subjectivity, embodiment, and music experience are gendered. Popular music and power are therefore indivisible.

The last presentation was held by John Shepherd, a longtime academic companion of Wicke. It is not by accident that Shepherd and Müller were in one panel as he has largely researched male hegemony and issues of gender in popular music. Shepherd called attention to "The Material Power of Music" to go beyond the binaries of text and context. He argues that music, as a highly organized and coded discourse, exercises power through a material and purely sonic technology of articulation that primarily addresses the body. He examined the tension around the debate of sound and meaning construction - between text (musicology) and context (cultural studies). The discussions, as stated by Shepherd, persisted well into the $21^{\text {st }}$ century and have centred on issues of music's social meanings, the character of social interaction and identity formation. From this debate, he identifies two sociologies of music: one practiced by music scholars with an interest in society 
and the other by sociologists with an interest in music; each perceived inadequate from the others perspective. He encouraged the development of a sociology of music that is also a sociology of music, with a solid foundation in contemporary sociological theory and methodology but sensible for the sonic materiality of music. He advocated the need for a co-construction analysis of music or one of mutual mediation.

In his concluding remarks, Wicke affirmed that he felt deeply honored to take part in this conference with such a diverse range of presentations, ideas and perspectives that sparked inspiring discussions. Wicke expressed his satisfaction with the development of the field of popular music studies and took the conference as evidence for the vitality of popular music studies today. He also took the opportunity to express his gratitude for all the bright students he had to help him understand further and deeper, and for his local and international colleagues for the support that had made it possible for him to study and work in East Berlin without feeling the limitations that one usually experienced. Finally, he shared a significant memory with the attendees: Berlin hosted a festival devoted to the political song in 1970s and 1980s in East Berlin. At one of those festivals he had found himself in his living room with two musicians who had performed there: one was Philip Tagg, the other one was Franco Fabbri. While drinking some beer and wine they discussed the need to bring more attention to the politics of popular music in the academic world because the few existing studies on a sociology of popular music - like those of Simon Frith or Paul Willis - were remarkable but too far away from the sound of music and the politics of sound. As no university seemed to be able to do this they agreed on founding an organization for this purpose. In the following months Tagg took all necessary steps for establishing a legal international organization which was the starting point for the International Association for the Study of Popular Music (IASPM). What is outstanding, said Wicke, is the struggle back then for the possibility to study and research popular music at all. The urge to call attention to the practice and the politics of popular music was in his opinion also the underlying common feature of the conference presentations. Despite the more sophisticated conditions and theoretical instruments of the present, this is still the connecting undercurrent and it remains, according to Wicke, a crucial issue for all scholars of popular music studies.

\section{References}

Shepherd, J. and Wicke, P. 1997. Music and Cultural Theory. Cambridge: Polity Press. Wicke, P. -

1990. Rock Music: Culture - Aesthetics - Sociology. Cambridge: Cambridge University Press.

1992. «Populäre Musik» als theoretisches Konzept. In PopScriptum 1: 6-42. 2009. The Art of Phonography: Sound, Technology and Music. In Derek B. Scott Ed.

The Ashgate Research Companion to Popular Musicology. Farnham: Ashgate: $147-168$. 
2016. The Sonic: Sound Concepts of Popular Culture. In Jens Gerrit Papenburg and Holger Schulze Ed. Sound as Popular Culture: A Research Companion. Cambridge, MA: MIT Press: 23-30.

2017. Looking East: Popular Music Studies between Theory and Practice. In Michael Ahlers and Christoph Jacke Ed. Perspectives on German Popular Music. London: Routledge: 33-51. 